\title{
Impact of Travel Information Search Behavior on the Image of Tanzania as a Tourist Destination
}

\author{
By Victor Gideon Wilson *
}

\begin{abstract}
Information has been noted to be the key to the formation of destination image. Destination marketers are aware of this fact and they aggressively try to influence the tourist's decisions by altering the image of their destinations through information provision. During their trip planning, tourists usually engage themselves with active information search. Despite motives being the crux of travel information search, it has only been conceptually linked to the travel information sources. In this research we focus on investigating the impact of information search behavior on the destination image. A questionnaire based survey was conducted to collect data from 625 tourists in Tanzania. The data were analyzed by employing factor analysis and relevant hypotheses were derived and tested by multiple regression analysis. The results suggested that the information search behaviors have a significant influence on the destination image Differential uses of different sources of information have different impact on the destination images and the longer the travel planning horizon the stronger the destination images. These findings offer a valuable empirical insights to the marketers as to where (sources) to put travel information to cater for different tourists having different motivations with the aim of influencing the destination image in a most favorable way.
\end{abstract}

\section{Introduction}

With the presence of diverse attractions and many tourism destinations to choose, the potential tourist is likely to face a difficult task in selecting a destination to travel to. Tanzania like any other destination finds itself in the big selection basket. Despite Tanzania being pegged second in terms of natural resources in the world after Brazil by the World Economic Forum (Blanke and Chiesa, 2011), it managed to capture a meager of $1.6 \%$ and $4.1 \%$ of the global tourist arrival and tourism receipts respectively (UNWTO, 2011). The untapped tourism potential in Tanzania shoulders a huge challenge to the destination marketer in knowing the potential tourists, being able to reach them with messages that can tilt their travel inclinations towards the country. These

*Assistant Lecturer, University of Dar es Salaam Business School, Tanzania.

https://doi.org/10.30958/ajt.1-2-3

doi=10.30958/ajt.1-2-3 
challenges necessitate an understanding of tourist information search behavior and destination image among others.

Information has been noted to be the key to the formation of destination image (Gartner, 1993). Destination marketers are aware of this fact and they aggressively try to influence the tourist's decisions by altering the image of their destinations through information provision. During their trip planning, tourists usually engage themselves with active information search (Fodness and Murray, 1997)). This search process has been amplified into how, why, and when (Hwang et al., 2002). The why of travel information search or the need for the information motivates and determines the information search behavior (Wilson, 2000). Despite motives being the crux of travel information search, it has only been conceptually linked to the travel information sources (Vogt and Fesenmaier, 1997) among other information search behavior variables. Tourists seek information in order to satisfy certain needs which define or refine their travel motives.

One way in which tourist eventually decide is through destination image which is an individual's mental representation of knowledge (beliefs), feelings and overall perception of a particular destination (Crompton, 1979). The image of a particular destination can influence tourist's choice among others. The role information plays in influencing the decision to visit a particular destination is in portraying the right image to the potential visitor. Given that destination image is the visitors' subjective perception of the destination reality (Chen and Tsai, 2007) the content and quality of information available when choosing a particular destination or when at a particular destination are important in portraying the rightful image. Thus information represents the important determinant of destination image formation. Lopes (2011) advances that information is very crucial in inducing a destination image on the potential visitors especially in context where tourist have no experience in locum and that through information it is possible to configure a stronger and lighter images of a destination. These all sum to the perceptions that visitors have on a particular destination. Thus it is important to investigate the relationship that exist between travel information search behavior and destination image Tanzania in particular as a tourist destination

\section{Literature Review}

\section{Travel Information Search Behavior}

It is a common knowledge that tourists are involved in pre purchase information search. Hwang et al., (2002) in amplifying the concept of tourist information search 'dimensionalized' it into 5 questions of who is searching, why is searching, what is sought, when it is sought, and how it is sought. The why question in the tourist information search reflects the motivation for seeking travel related information that can either be functional or nonfunctional (Vogt, Fesenmaier, and MacKay, 1993). The functional information needs are geared towards assisting a travel related decision while the non 
functional needs are consumed for other reasons like enjoyment, knowledge build up, and other reasons that are not related to an immediate travel decision to be made.

Information in tourism has been classified differently by different researchers. Some based on where the information is derived from (Gartner, 1993; Beerli and Martin, 2004a; Gitelson and Crompton, 1983; Money and Crotts, 2003) while few have based on when (Bieger and Laesser, 2004; Fodness and Murray, 1999) the information was obtained. Source of tourist information might include market dominated and non market dominated sources (Money and Crotts, 2003) where the destination marketers can have some control of the former but not for the latter. Such a perception is partially shared by Gartner (1993), where they categorized information source that influence destination image into overt induced, covert, autonomous, unsolicited organic, solicited organic, and organic. Basically the overt and covert are more inclined to the market dominated, and the others are non market dominated. Gitelson and Crompton (1983) categorized tourist information into friends and relatives, destination literature, consultants, broadcast media, and print media. Money and Crotts's (2003) categorization of information sources appears to be simplistic and more logical as well as being practical to the destination marketers will be employed in this study. The when aspect of tourist information search or what Gitelson and Crompton (1984) term as the planning horizon indicates how far in terms of time the tourists starts planning their foreseen vacations. Since time factor in the travel planning exerts a dynamic influence on the travel planning that have a consequential influence on the travel decisions basing on the destination image(s) held by the potential tourists, this study takes in board planning horizon.

\section{Destination Image}

Despite the importance of destination image concept in tourism and its long history in academics, there is no single firm agreeable definition for the concept (Gallarza, Saura, and Garcia, 2001). Reynolds (1965; in Gover and Go, 2009) defines destination image as the development of mental construct based upon few impressions chosen from a flood of information. This definition is adopted here as is not biased to any component of image and considers image as dynamic concept that depends on information acquired by the tourist. Destination image literature agrees that destination image can be broken into separate components that are interrelated; they include cognitive image, and affective image. The cognitive image consists of beliefs and knowledge about a destination and it primarily captures the tangible physical attributes; while the affective component focus on feelings about a destination (Lin et al.,2007). Outbound and long haul travel being expensive and time consuming implies the tourist to have tradeoffs in resource allocation that calls for cognitive destination image to play a greater role. Destination image being bifurcated into cognitive and affective components calls for studies that do factor both components. 


\section{Research Hypotheses and Conceptual Framework}

Information need is the initiator of information search process and behavior (Wilson, 1997). Quintal et al., (2011) upon researching the influence of risk avoidance and uncertainty avoidance on the extent of travel information search, noted the former to have no impact on the extent of travel information search compared to the latter having a positive impact. According to consumer information search (Hirschman... 1986) the risk and uncertainty avoidance falls within the functional information needs and thus neglecting the role of the non functional information search motives. Cho and Kerstetter (2004) in their study noted sign value of information that reflects the non functional information need as per Vogt and Fesenmaier's (1998) classification to be non functional.

Bieger and Laesser (2004) categorized information sources into those for making travel decision and those for preparation prior to travel, this echo Fondness and Murray's (1999) temporal and operational aspect. Despite capturing time element, their model does not offer much in destination image formation as the model starts at active information searching and not prior to that that might have created an image before that. Shiv and Fedorikhin (1999) argue that, the time when the subject comes into contact with information will determine the type of response (image) evoked into the subjects' mind and body. They relate time aspect and processing resources available to the subject at that time. When the processing resources are available, the subjects consciously process the information leading into cognitive image, while when the processing resources are less available, the subject unconsciously and automatically associate the information with others prior to cognition leading to affective image. Such an argument seem to suggest that information acquired during unmotivated travel phase of tourist (first visitors) is more likely to have affective dominant while those that are motivated and actively seek information will have the cognitive image as a dominant image. The temporal factor in determining the nature of destination image is shared by Gartner (1993), albeit its lack of specify on which component.

The influence of tourism information have been noted to a different decisive role in travel related decisions (Gitelson and Crompton, 1984; Bieger and Laesser, 2002) with those information received from friends and relatives that are more credible (Gartner, 1993) having a greater role in travel decisions. Baloglu (2001) on ascertaining the influence of the extent of information search that was factored in the familiarity construct noted it to have a differential influence on destination image. Since information is a constituent in destination image building, it is logical to assert that different sources of information will have a different effect on the destination image. Upon testing the effect of different sources of travel information on cognitive destination image, Beerli and Martin (2004a) noted a mixed and inconclusive effect.

H1: The information search behaviors have a significant influence on the destination image

H1a: Differential uses of different sources of information have different impact on the destination images. 
H1b: The longer the travel planning horizon the stronger the destination images.

\section{Methodology and Analysis}

This study used a self administered questionnaire to Tanzania inbound tourists. The departing tourists at the Julius Kambarage Nyerere International Airport, Kilimanjaro International Airport, and those who were consuming touristic products within the country were approached by trained research assistants who explained the objectives of the study and requested the tourists to participate in the study. Upon the consent of the tourists, they were given a copy of the questionnaire to fill in. The questionnaire had three main sections with all the questions being closed ended. The first section captured travel motives, information needs, and destination image items that were framed in 5 points Likert type scale with 1 indicating strong disagreement while 5 stood for strong agreement. The second section composed of questions capturing the tourist behavior while traveling and their travel planning processes; questions under this section required the respondent to select the appropriate answers. The last section captured the demographics of the tourists that included age, gender, country of residence, level of education, and monthly personal income.

A total of 650 questionnaires given to the tourists to fill in, after the removal of incomplete questionnaires a total of 625 questionnaires were used for analyses through the use of SPSS 21 program. The data were subjected to descriptive an inferential statistics. Descriptive statistics such as frequencies, means, and standard deviations served in exploring the general tendencies of the variables in that sample. Inferential statistics that were used were multiple regressions, Chi-square, and tests for means differences (t-tests and ANOVA).

\section{Sample Profile}

The sample profile is presented as Table 1 . The results indicate the sample to be gender balanced with both male and female percentages gyrating around $50 \%$. Educational wise the respondents appear to be relatively highly educated with about $83 \%$ having attained a university degree. Majority of the respondents appear to originate from European countries (58.7\%) followed by those coming from Americas (14.7\%) while those coming from Australia and Africa sharing relatively equal percentages (around 9\%). Those tourists coming from Asian countries composed about $4.6 \%$ of the sample while those from Middle East countries constituting the least visitors into Tanzania constituted about $2.4 \%$ of the sample. 
Table 1. Respondent Profile

\begin{tabular}{|c|c|c|}
\hline Variable & Frequency (mean) & $\%$ (stdev.) \\
\hline Gender & 309 & 49.6 \\
Male & 314 & 50.4 \\
Female & & \\
Level of education & 17 & 2.8 \\
Less than high school & 80 & 13.3 \\
Less than college & 382 & 63.3 \\
University degree & 124 & 20.6 \\
Postgraduate degree & 367 & \\
Country of residence & 92 & 58.7 \\
Europe & 29 & 14.7 \\
America & 60 & 4.6 \\
Asia & 56 & 9.6 \\
Australia/New Zealand & 15 & 9.0 \\
Africa & $(35.62)$ & 2.4 \\
Middle East & & $(12.60)$ \\
\hline Age in years &
\end{tabular}

Travel Behaviour and Sources of Information Used

The frequencies and percentages related to travel behavior of the respondents and the way the planned their Tanzanian trip are displayed as Table 2. About $84.8 \%$ of the respondents indicated to have planned for the current Tanzanian trip for more than a month indicating Tanzania to be a true long haul destination for the tourists. Only $12.3 \%$ of the respondents indicated to have made less than $25 \%$ of their travel decisions prior to their date of travel to Tanzania giving further support to the country being a long haul destination. The distribution of travel mode between the three modes do not differ much with those traveling as fully package being $35.2 \%$ of the respondents while those traveling as partly package and fully independent tourists representing $28.4 \%$ and $36.4 \%$ of the respondents respectively. Those who are traveling with their spouse and with their friends or relatives each comprise about $32 \%$ of the respondents while those who are traveling alone made about $15 \%$ of the respondents. Those traveling as a family either with spouse and children or with one parent and children were few representing only $7.7 \%$ of the respondents. Approximately $70 \%$ of the inbound tourists to Tanzania can be considered as leisure tourists.

Table 2. Travel Behavior and Travel Planning

\begin{tabular}{|c|c|c|}
\hline Variable & Frequency & $\%$ \\
\hline Planning horizon & 29 & 4.6 \\
One Week & 66 & 10.6 \\
Within a month & 215 & 34.5 \\
1-3 months & 154 & 24.7 \\
3-6 months & 160 & 25.6 \\
\hline
\end{tabular}




\begin{tabular}{|c|c|c|}
\hline 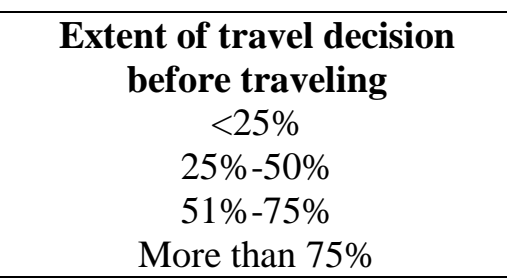 & $\begin{array}{c}75 \\
113 \\
183 \\
237 \\
\end{array}$ & $\begin{array}{l}12.3 \\
18.6 \\
30.1 \\
39.0\end{array}$ \\
\hline $\begin{array}{c}\text { Travel mode } \\
\text { Fully package } \\
\text { Partly package } \\
\text { Fully independent }\end{array}$ & $\begin{array}{l}216 \\
174 \\
223\end{array}$ & $\begin{array}{l}35.2 \\
28.4 \\
36.4\end{array}$ \\
\hline $\begin{array}{c}\text { Travel party } \\
\text { Alone } \\
\text { With spouse } \\
\text { With children } \\
\text { Spouse and children } \\
\text { Friends/relatives } \\
\text { Other }\end{array}$ & $\begin{array}{c}97 \\
204 \\
17 \\
31 \\
202 \\
71\end{array}$ & $\begin{array}{c}15.6 \\
32.8 \\
2.7 \\
5.0 \\
32.5 \\
11.4\end{array}$ \\
\hline $\begin{array}{c}\text { Travel purpose } \\
\text { Leisure } \\
\text { Visiting friends/relatives } \\
\text { Conference } \\
\text { Business } \\
\text { Other }\end{array}$ & $\begin{array}{c}424 \\
54 \\
16 \\
48 \\
65\end{array}$ & $\begin{array}{c}69.9 \\
8.9 \\
2.6 \\
7.9 \\
10.7\end{array}$ \\
\hline $\begin{array}{c}\text { Length of stay } \\
<5 \text { nights } \\
6-10 \text { nights } \\
11-20 \text { nights } \\
>20 \text { nights }\end{array}$ & $\begin{array}{c}70 \\
222 \\
212 \\
121\end{array}$ & $\begin{array}{l}11.2 \\
35.5 \\
33.9 \\
19.4\end{array}$ \\
\hline Travel with children under 18 & 55 & 8.9 \\
\hline $\begin{array}{c}\text { Travel group size } \\
\text { Alone } \\
\text { 2 persons } \\
\text { 3-4 persons } \\
\text { 5-7 persons } \\
>7 \text { persons }\end{array}$ & $\begin{array}{c}98 \\
315 \\
116 \\
42 \\
53\end{array}$ & $\begin{array}{c}15.7 \\
50.5 \\
18.6 \\
6.7 \\
8.5\end{array}$ \\
\hline
\end{tabular}

The knowledge of the sources of tourist/travel information used assist destination marketers to know where to place their promotion communication. In ascertaining the sources of travel information, a question capturing the percentages of usage of particular information was included in the questionnaire with the resulting information being presented as Table 3. The Table also indicates the respective ranking on the usage of each of the sources of travel information for groups using from and above $25 \%-50 \%$ of a particular sources of travel information. Internet as a source of travel information appears to be the main source of information by being used to a larger extent. Information from friends and relatives is also relatively more used by the tourist compared to travel/magazines but not to the extent of internet. 
Advertisements/media and trade fairs/exhibitions are hardly used by the tourists as the source of travel information. Since same respondents had the destination image in mind, the factor analysis indicates that there is a relationship between these various sources of information and the destination image (Table 4). A Chi-square test for the independent of the various sources of information confirms that the different use of different sources of information has significant impact on destination image.

Table 3. Sources of Travel Information

\begin{tabular}{|c|c|c|c|c|c|}
\hline \multirow{2}{*}{ Source of information } & \multicolumn{5}{|c|}{ Frequency of usage (rank) } \\
\cline { 2 - 6 } & NIL & $25 \%$ & $\begin{array}{c}26 \%- \\
50 \%\end{array}$ & $\begin{array}{c}51 \%- \\
75 \%\end{array}$ & $>75 \%$ \\
\hline Travel books/Magazine & 137 & 159 & $124(1)$ & $101(3)$ & $94(3)$ \\
\hline Hotel/restaurant & 271 & 199 & $71(4)$ & $41(4)$ & $26(6)$ \\
\hline Tourist information centers & 276 & 176 & $68(5)$ & $38(6)$ & $52(4)$ \\
\hline Advertisements/Media & 303 & 190 & $56(6)$ & $41(5)$ & $22(7)$ \\
\hline Trade fair/exhibitions & 363 & 166 & $38(7)$ & $27(7)$ & $16(8)$ \\
\hline Internet & 20 & 76 & $107(2)$ & $134(2)$ & $281(1)$ \\
\hline Friends and relatives & 123 & 146 & $105(3)$ & $143(1)$ & $99(2)$ \\
\hline Others & 156 & 56 & $12(8)$ & $19(8)$ & $31(5)$ \\
\hline
\end{tabular}

Factor Analysis and Reliability Test

Prior to the performance of inferential tests, it is important to ascertain the validity and reliability of the measurement items. The validity for the items in this study is ascertained by factor analysis (PCA, Varimax) and the results are presented in Table 4 together with the reliability analysis (Cronbach alpha). For The eight destination image items clearly loaded into their respective factors of cognitive image, cultural image, and affective image with Cronbach alpha being above .60 .

Table 4. Factor Analysis and Reliability Tests Destination Image

\begin{tabular}{|c|c|c|c|c|c|c|}
\hline \multirow{2}{*}{ Variable/items } & \multirow{2}{*}{ Mean } & \multirow{2}{*}{ Stdev. } & \multicolumn{3}{|c|}{ Factor loadings } & \multirow{2}{*}{$\begin{array}{l}\text { Cronbach's } \\
\text { alpha }\end{array}$} \\
\hline & & & Factor 1 & Factor 2 & Factor 3 & \\
\hline Cognitive image & & & & \multirow{13}{*}{$\begin{array}{l}.863 \\
.810\end{array}$} & \multirow{13}{*}{$\begin{array}{l}.911 \\
.873\end{array}$} & \multirow{9}{*}{.690 } \\
\hline Rich in & & & & & & \\
\hline flora/fauna & 4.51 & .800 & & & & \\
\hline $\begin{array}{l}\text { Mesmerizing } \\
\text { landscape }\end{array}$ & 4.43 & .812 & & & & \\
\hline Good beaches & 4.29 & .981 & & & & \\
\hline Cultural Image & & & & & & \\
\hline Many historical/ & & & & & & \\
\hline culture & 3.81 & 1.009 & & & & \\
\hline Lots of cultural & 3.71 & 1.085 & & & & \\
\hline Affective Image & & & & & & \multirow{2}{*}{.791 } \\
\hline Boring & 1.51 & 1.025 & .832 & & & \\
\hline destination & 1.65 & 1.054 & .848 & & & \multirow[t]{2}{*}{.752} \\
\hline $\begin{array}{c}\text { Unpleasant } \\
\text { Gloomy }\end{array}$ & 2.00 & 1.341 & .761 & & & \\
\hline
\end{tabular}




\section{Regression Analysis}

The study tested the relationship between the three destination image factors and the influencing factor planning horizon which composed of the time tourists started planning to visit Tanzania and the extent tourists made their travelling decisions before travelling to the tourist destination. The coefficient of determination $\left(\mathrm{R}^{2}\right)$ value shows that $0.4 \%$ and $1.4 \%$ of the variance associated with cognitive and cultural destination image respectively is explained from the independent variables, of opposite no variations are explained under the affective destination image $\left(\mathrm{R}^{2}=0.0 \%\right)$. According to Hair et al (2006) the Durbin-Watson value of 1.804 for determinants of cognitive destination image (Table 5) and 1.590 for determinants of cultural destination image (Table 6) and 1.641 for the determinants of affective (Table 7) where all are between 1.5 and 2.5 demonstrate that there are no auto correlation problems in the data used in this study.

Table 5. Results of Multiple Regressions; Cognitive Image

\begin{tabular}{|c|c|c|c|c|c|}
\hline & & & \multicolumn{3}{|c|}{ Standardized Coefficients } \\
\hline Variable & B & SE & Beta & t-value & Sig \\
\hline (Constant) & .015 & .166 & & .093 & .926 \\
\hline Travel Planning & .038 & .039 & .043 & .961 & .337 \\
\hline Travel Decisions & -.056 & .042 & -.061 & -1.355 & .176 \\
\hline
\end{tabular}

Notes: $F=1.120$, sig. $F$ change $=0.327 ; R^{2}=0.004$; Durbin-Watson $=1.804$

Table 6. Results of Multiple Regressions; Cultural Image

\begin{tabular}{|c|c|c|c|c|c|}
\hline & & & \multicolumn{3}{|c|}{ Standardized Coefficients } \\
\hline Variable & $\mathrm{B}$ & SE & Beta & $\mathrm{t}$-value & Sig. \\
\hline (Constant) & -.096 & .170 & & -.567 & .571 \\
\hline Travel Planning & .101 & .040 & .111 & 2.507 & .012 \\
\hline Travel Decisions & -.091 & .043 & -.095 & -2.132 & .034 \\
\hline
\end{tabular}

Notes: $F=4.328$, sig. $F$ change $=0.014 ; R^{2}=0.016$; Durbin-Watson $=1.590$

Table 7. Results of Multiple Regressions; Affective Image

\begin{tabular}{|c|c|c|c|c|c|}
\hline & & & \multicolumn{3}{|c|}{ Standardized Coefficients } \\
\hline Variable & B & SE & Beta & t-value & Sig. \\
\hline (Constant) & -.032 & .170 & & -.186 & .853 \\
\hline Travel Planning & -.006 & .040 & -.007 & -.152 & .879 \\
\hline Travel Decisions & .015 & .043 & .016 & .352 & .725 \\
\hline
\end{tabular}

Notes: $F=0.064$, sig. $F$ change $=0.938 ; R^{2}=0.000 ;$ Durbin-Watson $=1.641$

The analysis of the empirical data derived from the survey of inbound tourists revealed many lessons that will be of great value to destination marketers. As expected the tourist who plans long prior to traveling to the destination had the strong image of the touring destination, but the study found less strong direct significant relationship. There was a very partial relationship with only tourist with cognitive and cultural image. The planning horizon doesn't have any impact towards the destination image in Tanzania. Thus there is enough statistical evidence to reject the hypothesis that information search 
behavior has strong positive relationship with destination image. The t-values indicate the negative influences of the independent factors towards all the three cases of the destination image, resulting to no significant contribution to tourists.

\section{Conclusion}

This study sought empirical support for a research hypothesis that enlightens the destination marketers on tourist destination image. Towards that end, the study was partially successful. The data collected from inbound tourists for more than three months generally supported the overall validity of the destination image variables and the hypotheses. With slight differences in the magnitude the parameter estimates are basically the same in all three cases of the hypothesis testing in terms of direction and relative strength of each factor. The results showed that even though internet as the source of tourist information (ranked first) been the prime source, others sources have shown the significant contribution towards destination image (Table 3). The government of Tanzania with its tourist boards/agencies and the destination marketers should strive to improve the ICT to enable the world to Tanzania as their destination image and capture the mass tourist arrival (Blanke and Chiesa, 2011).

Also no significant, direct relationship was found between planning horizon and destination image, this being the basis of rejecting the H1b. of interest the affective destination image showed the negative relationship on which the items represent the true feelings of the respondents, the respondents where provided with three kind of feelings i.e. boring, unpleasant, and gloomy destination, their responses indicated that they actually felt inline. Since the respondents were inbound tourists, they could not plan to travel to such kind of destination; this might be the main reason to rejecting the hypothesis (H1b).

The study findings arise a need to have an exploratory study, exploring cognitive and affective factors on destination image. The studied factors in this study adopted from Lin et al (2006) and Laws (1995) that capture the physical, there is more to be done in developing country where the majority have negative cognitions. Furthermore there is a need for further studies using different methods to test the significant relationship between the planning horizon and tourist destination image.

Acknowledgments: My sincere appreciation goes to ATINER for allowing this template to be modified to fit in my research paper. Many thanks also to the government of Denmark under the BSPS phase III project at the University of Dar es Salaam Business School to facilitate my data collection and writing up this paper.

\section{References}

Ahmed, Z., Sohail, M, and San, C. (2006). Marketing of Australia to Malaysian consumers. Service Marketing Quartely, 28(2), 54-78. 
Baloglu, S. (1999). A path analytic model of visitation intention involving information sources, socio-psychlogical motivations, and destination image. Journal of Travel and Tourism Marketing, 8(3), 81-90.

Blanke, J. and Chiesa, T. (2011). The Travel and Tourism Competitive Report 2011. Worl Economic Forum. Geneva, Switzerland.

Baloglu, S. and McCleary, K.W. (1999). U.S. international pleasure travelers' images of four Mediterranean destinations: a comparison of visitors and nonvisitor. Journal of Travel Research, 38, 144-152.

Beerli, A. and Martin, J.D. (2004a). Factors influencing destination image. Annals of Tourism Research, 31(3), 657-681.

Beerli, A. and Martin, J.D. (2004b). Tourists' characteristics and the perceived image of tourist destinations: a quantitative analysis-a case study of lanzorote, Spain. Tourism Management, 25, 623-636.

Cho, M.H. and Kerstetter, D.L. (2004). The influence of sign value on travel-related information search. Leisure Science, 26, 19-34.

Crompton, J.L. (1979). Motivations for pleasure vacation. Annals of Tourism Research, 4(4), 408-424.

Dey, B. and Sarma, M.K. (2010). Information source usage among motive-based segments of travelers to newly emerging tourist destinations. Tourism Management, 31, 341-344.

Dolnicar, S., Laesser, C., and Matus, K. (2009). Online versus paper: format effects on tourism surveys. Journal of Travel Research, 47(3), 295-316.

Fondness, D. (1994). Measuring tourist motivation. Annals of Tourism Research, 21(3), 555-581.

Hair, J.F., Black, W.C., Babin, B.J, Anderson, R.E. and Tatham, R.L. (2006), Multivaliate Data Analysis, $6^{\text {th }}$ ed., Prentice-Hall, Upper Saddle River, NJ.

Hwang, Y.H., Gretzel, U. and Fesenmaier, D.R. (2002). Behavioral foundations for human-centric travel decision aid systems. In Wober, K.W., Frew, A.J. and Hitz, M. (Editors). Information and Communication Technology in Tourism, SpringerWien, NY, 356-365.

Laws, E. (1995). Tourism Destination Management, Issues, Analysis and Policies. Routledge, New York.

Lin, C.H., Morais, D.B., Kerstetter, D.L. and Hou, J.S. (2007). Examining the role of cognitive and affective image in predicting choice across natural, developed and theme-park destinations. Journal of Travel Research, 46(2), 183-194.

MacKay, K.J. and Fesenmaier, D.R. (1997). Pictorial element of destination image formation. Annals of Tourism Research, 24(3), 537-565.

Martin, H.S. and del Bosque, I.A.R. (2008). Exploring the cognitive-affective nature of destination image and the role of psychological factors in its formation. Tourism Management, 29, 263-277.

Martin, H.S. and Rodrigues del Bosque, I.A. (2008). Exploring the cognitive-affective nature of destination image and the role of psychological factors in its formation. Tourism Management, 29, 263-277.

Matos, N., Mendes, J., and Valle, P. (2012). Revisiting the destination image construct through a conceptual model. Dos Algarves: A Multidisciplinary e-Journal, 21, 102-117. Available at http://www.dosalgarves.com/revistas/N21/5rev21.pdf (accessed on 12/10/2012, 10:30am)

Prayag, G. (2010). Images as pull factors of a tourist destination: a factor-cluster segmentation analysis. Tourism Analysis, 15.

Uysal, M. and Jurowski, C. (1994). Testing the Push and Pull factors. Annals of Tourism Research, 21(40, 844-846. 
Uysal, M., Li, X. and Sirikaya, E. (2008). Push-pull dynamics in travel decisions. in Pizam, A. and Oh, H. (Editors), Handbook of Hospitality Marketing Management, M.A. USA: Butterworth-Heinemann.

Veal, A.J. (2006). Research Methods for leisure and Tourism: A Practical Guide ( $3^{\text {rd }}$ Edition). Pearson Education Limited, Essex, England. 